\title{
SYMPHYTOCARPUS TRECHISPORUS (MYXOGASTREA) IN POLAND
}

\author{
AgnieszKa Salamaga ${ }^{1}$, Barbara Grzesiak, Magdalena Kochanowska \\ \& JANUSZ KOCHANOWSKI
}

\begin{abstract}
Symphytocarpus trechisporus (Berk. ex Torrend) Nann.-Bremek. is rare in Poland, known previously from only one locality. Sixty years after the original report, this paper presents two new localities of it in separate regions of Poland. Although $S$. trechisporus is recorded mostly on Sphagnum sp., the taxon does not seem to be attached to a specific substrate; rather it is associated with acidic habitats.
\end{abstract}

Key words: distribution, ecology, Myxogastrea, Poland, slime molds, Symphytocarpus trechisporus

Agnieszka Salamaga, Institute of Botany, Jagiellonian University, Kopernika 27, 31-501 Kraków, Poland; e-mail: asalamaga@wp.pl Barbara Grzesiak, Department of Algology and Mycology, University of Łódź, Banacha 12/16, 90-237 Lódż, Poland; e-mail: grzesiak@biol.uni.lodz.pl

Magdalena Kochanowska \& Janusz Kochanowski, Park Narodowy “Bory Tucholskie”, Dtuga 33, 89-606 Charzykowy, Poland; pdn@pnbt.com.pl;j.kochanowski@pnbt.com.pl

\section{INTRODUCTION}

The genus Symphytocarpus was first described by Ing and Nannenga-Bremekamp in 1967 as intermediate between the genus Amaurochaete Rostaf. and the genera Stemonitis Gled. and Comatricha Preuss. Ing and Nannenga-Bremekamp (1967) transferred to Symphytocarpus species of related genera whose sporocarps were partly merged, forming a pseudoaethalium, without a surface net and with a furfuraceous peridium. At present the genus contains nine species (Lado 2005-2014). Four of them have been recorded in Poland: Symphytocarpus amaurochaetoides Nann.-Bremek., S. confluens (Cooke \& Ellis) Ing \& Nann.-Bremek., S. flaccidus (Lister) Ing \& Nann.-Bremek. and S. trechisporus (Berk. ex Torrend) Nann.-Bremek. (Drozdowicz et al. 2003). Two of them (S. flaccidus, S. trechisporus) are on the red list of Myxomycetes rare in Poland (Drozdowicz et al. 2006). Symphytocarpus trechisporus was recorded only once, by Szulczewski (1951), in Wielkopolski National Park. Here we present two new localities of it, recorded in central and northwestern Poland (Fig. 1).

\footnotetext{
1 Corresponding author
}

\section{MATERIALS AND METHODS}

The material was collected in the field in 2011 and 2014, and observed with a Nikon SMZ 745T stereomicroscope and a Nikon YS100 light microscope. Permanent slides were made using Hoyer's medium. Spores ( 30 per collection) were measured at $100 \times$ using an oil immersion objective. Photographs were taken with a Nikon D7000 and a Nikon H600L light microscope. Spore ornamentation was observed on air-dried specimens with a JEOL JSM 5410 scanning electron microscope. SEM micrographs were taken in the Department of Cell Biology and Imaging at the Institute of Zoology, Jagiellonian University, Kraków.

The specimen from the Święte Ługi Nature Reserve is deposited in the Herbarium of the Łódź University (LOD). A duplicate and permanent preparations are deposited in the MYXO division of the herbarium of the Institute of Botany, Jagiellonian University (KRA). The specimen from Bory Tucholskie National Park and permanent preparations are deposited in the MYXO division of the herbarium of the Institute of Botany, Jagiellonian University (KRA).

For comparison we obtained on loan a specimen of $S$. trechisporus and a type specimen of $S$. cristatus Nann.-Bremek. from the National Botanical Garden, Meise, Belgium (BR). 


\section{RESULTS AND DISCUSSION}

Symphytocarpus trechisporus (Berk. ex Torrend) Nann.-Bremek.

Figs $1 \& 2$

Proc. Kon. Ned. Akad. Wetensch., C 70(2): 219. 1967. - Stemonitis fusca var. trechispora Berk. ex Torrend, Brotéria, Sér. Bot. 7: 81. 1908. Stemonitis trechispora (Berk. ex Torrend) T. Macbr., N. Amer. Slime-moulds, ed. 2: 159. 1922.

Sporocarps dark brown, clumped, elongated, cylindrical, high, 2-3 mm in diameter, often irregularly shaped due to clumping, subsessile. Stalk absent or very short, dark brown, 0.017-1 mm long. Hypothallus shining, brown. Peridium evanescent. Columella almost reaching sporocarp apex, of variable width, sometimes broader at base and tapering towards apex. Capillitium brown, branching from the columella as a net with membranous axils, with free ends at surface (not forming surface net). Spores dark brown in mass, globose, 10-12(-14) $\mu \mathrm{m}$. Spore ornamentation typical in most spores: complete reticulum. Some spores having incomplete reticulum.

Material eXAMined: POLAND. (1) $C a 60 \mathrm{~km} \mathrm{SW}$ of Łódź, Święte Ługi Nature Reserve $\left(51^{\circ} 23^{\prime} 15^{\prime \prime} \mathrm{N}\right.$,

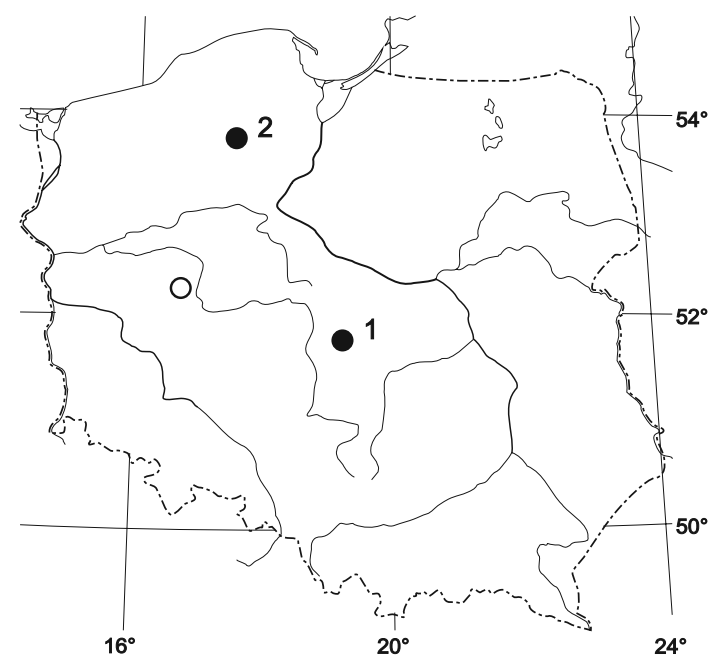

Fig. 1. Distribution of Symphytocarpus trechisporus (Berk. ex Torrend) Nann.-Bremek. in Poland. O - known locality, - new localities (1 - Święte Lugi Nature Reserve; 2 - Bory Tucholskie National Park). $\left.19^{\circ} 6^{\prime} 21^{\prime \prime E}\right)$, Eriophorum vaginatum-Sphagnum fallax plant association, on Polytrichum sp., 22 Aug. 2011, leg. B. Grzesiak (KRA 10816); (2) Ca $10 \mathrm{~km}$ west of Chojnice, Bory Tucholskie National Park, Scheuchzerietalia palustris plant association $\left(53^{\circ} 49^{\prime} 41^{\prime \prime} \mathrm{N}, 17^{\circ} 33^{\prime} 47^{\prime \prime} \mathrm{E}\right)$, on Sphagnum sp., 20 July 2014, leg. A. Salamaga (KRA 10817).

REMARKs. Generally the macro- and micromorphological characters of our specimens are consistent with the description of the species, but we also observed spores of different size and ornamentation in the slide preparations. The ornamentation of the spores in the collection from the first locality posed special difficulties. In the slide preparations we observed spores with a complete reticulum as well as with an incomplete reticulum with lax bands, which is a characteristic trait of S. cristatus. Rammeloo (1975) presented spore micrographs of $S$. trechisporus with ornamentation ranging from an incomplete to an almost complete reticulum, but information on such variation of spore ornamentation in the species is not given in the keys (Ing 1999; Poulain et al. 2011b). For this reason we compared our material with specimens of $S$. cristatus and $S$. trechisporus loaned from the National Botanic Garden, Belgium (Figs 2f \& 3). Each loaned specimen proved to have spore ornamentation characteristic of its species. Thus, with the exception of spores with atypical ornamentation, all other morphological traits of our specimen from the first locality are characteristic of $S$. trechisporus. In the second collection we observed spores showing characteristic ornamentation and a complete reticulum but they were slightly larger (11-12 $\mu \mathrm{m}$ in size) than in those of the first specimen. There were single spores up to $14 \mu \mathrm{m}$ in size. The maximum spore size reported in the literature is $13 \mu \mathrm{m}$ (Ing 1999). We suggest that these differences are due to fact that the sporocarps collected at both localities, especially at the first one, were not fully developed.

The taxon occurs on acid mires where Sphagnum sp. predominates (Ing 1999) and apparently is associated with the habitat, not the substrate. Our specimen from the first locality was found on Polytrichum sp., and the one from 

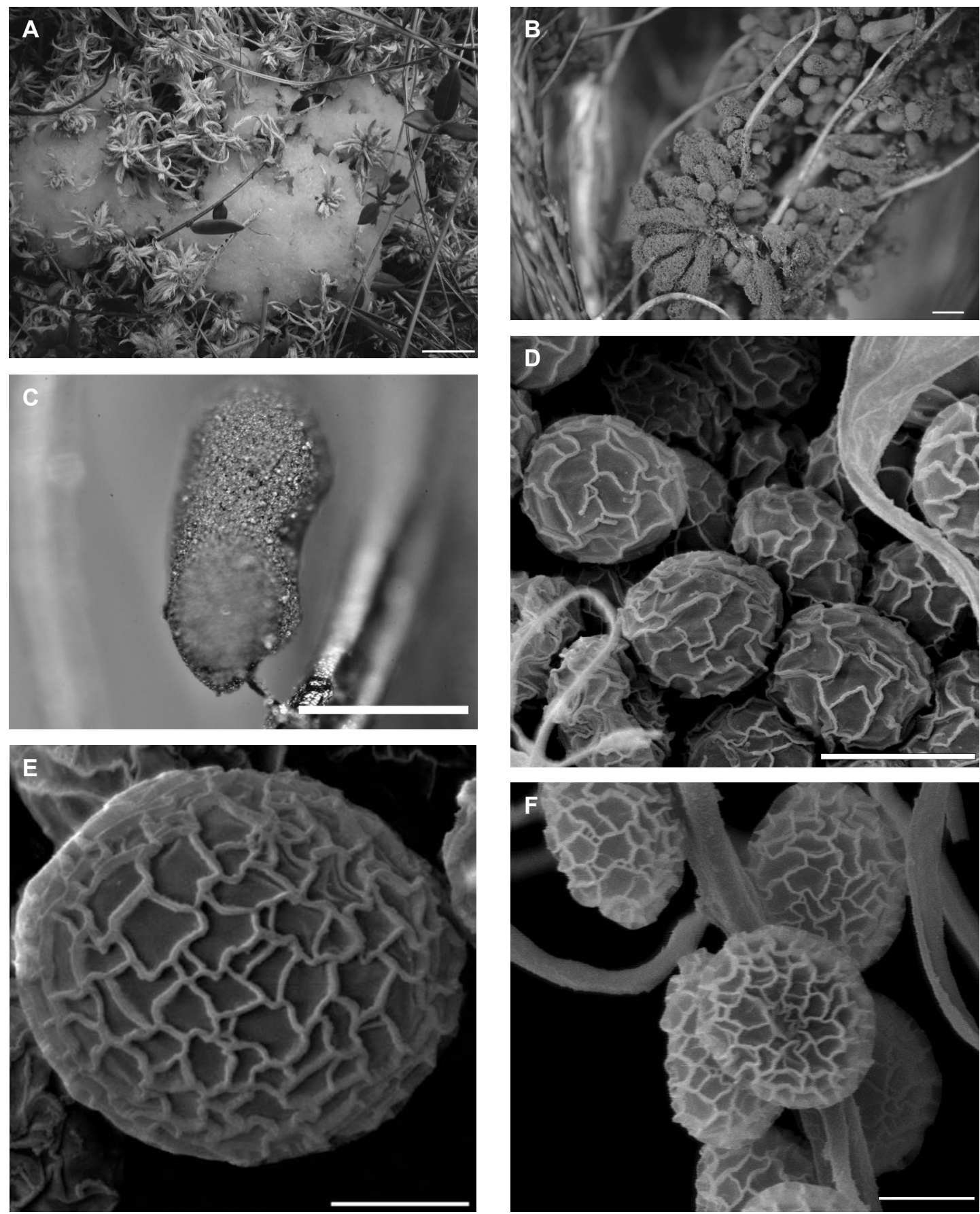

Fig. 2. Symphytocarpus trechisporus (Berk. ex Torrend) Nann.-Bremek. A - white, immature pseudoaethalium, B - pseudoaethalium, C - sporocarp with stalk, D - spores with incomplete reticulum, E - spores with complete reticulum, $\mathrm{F}$ - spores (A - A. Salamaga, KRA 10817; B-E - B. Grzesiak, KRA 10816; F - Nannenga 2071, BR MYCO-052080-88). Scale bars: $\mathrm{A}-\mathrm{C}=1 \mathrm{~mm}, \mathrm{D}=8 \mu \mathrm{m}, \mathrm{E}=4 \mu \mathrm{m}, \mathrm{F}=6 \mu \mathrm{m}$. 


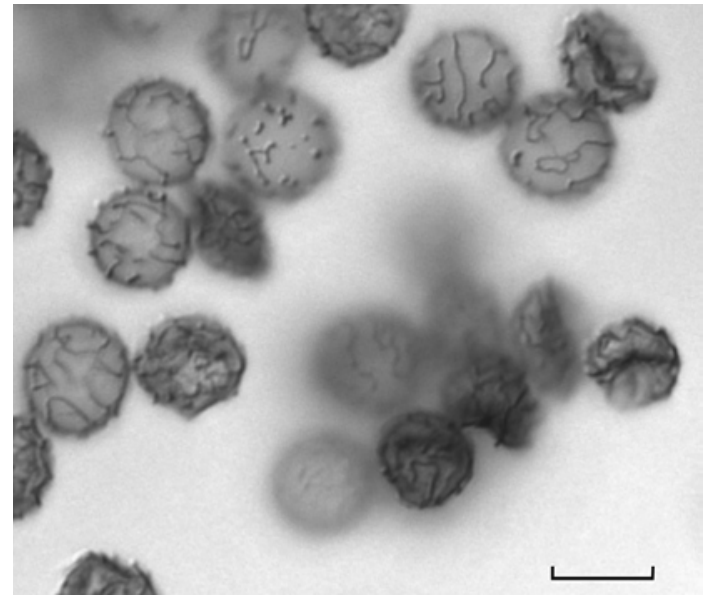

Fig. 3. Spores of Symphytocarpus cristatus Nann.-Bremek. (Nannenga 2964, BR - MYCO - 052956 - 91). Scale bar $=10 \mu \mathrm{m}$.

the second locality was found on Sphagnum sp., as similarly reported in Scotland, England and Germany (Ing 1999; Schnittler et al. 2011). It has also been recorded on wood of Liriodendron sp. in moist chamber cultures (Härkönen et al. 2004). Szulczewski (1951) reported finding $S$. trechisporus on wood but gave no information on the type of the habitat colonized.

Symphytocarpus trechisporus is a rare species. The literature notes few localities in Europe and worldwide (Adamonyte 2003; Härkönen et al. 2004; Ing 1999; Lado \& Wrigley de Basanta 2008; Nannenga-Bremekamp 1991; Neubert et al. 2000; Van Hoof 2006). In Poland the species was known previously from only one locality and is red-listed as a rare myxomycete. It is also reported as rare in Germany (Schnittler et al. 2011). We attribute its rarity in Poland to its preference for colonizing acid habitats: a variety of peat bogs. In Poland, investigations of the myxomycetes in these types of habitats have not been conducted. The specimen collected at the first locality was found by accident during research on bryophilous fungi occurring in peat bogs. With the ecology of the species in mind, we paid special attention to this type of habitat when studying slime molds in the Bory Tucholskie National Park; as a result, the second locality of the species was discovered.
AcKnowledgments. We thank Dr. Anna Ronikier (Kraków) for valuable comments on the manuscript and for assistance with the determination of the specimen collected at the first locality, Dr. Tetiana Kryvomaz (Kiev) and Dr. Grazina Adamonyte (Vilnius) for valuable comments on the submitted manuscript, Dr. Joanna Kazik (Łódź) for reviewing the English, and Assistant Curator Ann Bogaerts of the National Botanical Garden (Meise, Belgium) for kindly lending collections for comparison with our specimens.

\section{REFERENCES}

Adamonyte G. 2003. Myxomycetes of the genus Symphytocarpus Ing et Nann.-Bremek. in Lithuania. Botanica Lithuanica 9(1): 55-63.

Drozdowicz A., Ronikier A., Stojanowska W. \& Panek E. 2003. Myxomycetes of Poland. A checklist. W. Szafer Institute of Botany, Polish Academy of Sciences, Kraków.

Drozdowicz A., Ronikier A. \& Stojanowska W. 2006. Red list of rare Myxomycetes in Poland. In: Z. MireK, K. Zarzycki, W. WoJeWoda \& Z. SzeląG (eds), Red list of plants and fungi in Poland, pp. 91-99. W. Szafer Institute of Botany, Polish Academy of Sciences. Kraków.

HärkÖNEN M., RikKINEN J., UKKOLA T., ENROTH J., VIRTANEN V., JäÄskeläinen K., Rinne E., Hiltunen L., Piippo S. \& HE X. 2004. Corticolous Myxomycetes and other epiphytic cryptogams on seven native tree species in Hunan Province, China. Syst. Geogr. Pl. 74(1): 189-198.

ING B. 1999. The Myxomycetes of Britain and Ireland. The Richmond Publishing Co. Ltd., Slough.

Ing B. \& NANNEnga-Bremekamp N. E. 1967. Notes on Myxomycetes XIII. Symphytocarpus nov. gen. Stemonitacearum. Proc. Kon. Ned. Akad. Wetensch., Ser. C., Biol. Med. Sci. 70(2): 218 .

LADO C. 2005-2014. An on-line nomenclatural information system of Eumycetozoa. [June 2014]. http://www.eumycetozoa.com.

Lado C. \& Wrigley de Basanta D. 2008. A review of Neotropical Myxomycetes (1828-2008). Anales Jard. Bot. Madrid 65(2): 211-254.

NAnnenga-Bremekamp N. E. 1991. A guide to temperate Myxomycetes. Biopress Ltd., Bristol.

Neubert H., Nowotny W., Baumann K. \& Marx H. 2000. Die Myxomyceten Deutschlands und des angrenzenden Alpenraumes unter besonderer Berücksichtigung Österreichs. 3. Karlheinz Baumann Verlag, Gomaringen.

Poulain M., Meyer M. \& Bozonnet J. 2011. Les Myxomycetes. Guide de détermination. 1. Fédération Mycologique et Botanique Dauphiné-Savoie, Sevrier. 
Rammeloo J. 1975. Structure of the epispore of the Stemonitales (Myxomycetes) as seen with the scanning electron microscope. Bull. Jard. Bot. Natl. Belg. 45: 301-306.

Schnittler M., Kummer V., Kuhnt A., Krieglsteiner L., Flatau L. \& MÜller H. 2011. Rote Liste und Gesamtartenliste der Schleimpilze (Myxomycetes) Deutschlands. Naturschutz und Biologische Vielfalt. In: G. LudwiG \& G. Matzke-HajeK (eds), Rote Liste gefährdeter Tiere,
Pflanzen und Pilze Deutschlands 6(2): 125-234 Landwirtschaftsverlag $\mathrm{GmbH}$, Bonn.

Szulczewski J. W. 1951. The Myxomycetes of the National Park of Great Poland. Prace Monogr. Przyr. Wielkopolsk. Parku Nar. Poznaniem 2(7): 1-11 (in Polish with English and Russian summaries).

Van Hooff H. 2006. A standard list of names for the Dutch species of Myxomycetes. Coolia 49(4): 204-219.

Received 8 September 2014 